\title{
Chief to leave troubled British Biotech
}

[LONDON] The founder of one of Britain's first and largest biotechnology companies, British Biotech, is to resign as chief executive in an attempt to bolster shareholders' confidence in the embattled company.

The announcement of Keith McCullagh's departure was made last week in a package of measures aimed at stemming the tide of bad news that has seen the company's share price tumble (see Nature 392, 852; 1998).

But some analysts believe that the measures maybe insufficient to restore confidence in the company. They add that the episode has taught the financial community to treat assessments of the state of biotechnology company drugs trials more cautiously.

The measures announced by British Biotech, which is based in Oxford, include redundancies for 42 of the company's 300 staff. British Biotech will also seek partners in the United States to help to market its anticancer drug marimastat.

McCullagh will leave his post in September. His resignation was effectively forced on British Biotech following alleged insider trading, an investigation into alleged misleading statements on the progress of drugs trials and allegations that the company withheld bad news from the stock market on the progress of drugs trials.

Many of the allegations were made by Andrew Millar, the company's former director of clinical research, who was sacked for disclosing his concerns to the company's shareholders (see Nature 392, 746; 1998).

In a 32-page circular to shareholders, the company denies all allegations of impropriety. But some analysts feel that it raises more

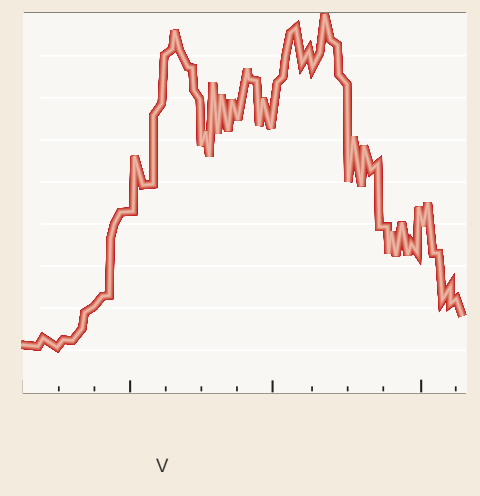

questions than it tries to answer. For example, the circular says there is "no substance" to allegations that directors — including McCullagh — sold British Biotech shares before telling the London Stock Exchange of problems with the trials of an anticancer drug, batimastat.

The circular says that "serious adverse events" with batimastat were first reported in November 1994. The trial was eventually suspended following a board meeting on 16 February 1995 and an announcement was made the following day. A decision by the directors to sell their shares, by contrast, was taken on 15 December 1994 - before the board decided to suspend the trials.

Nick Woolf, European biotechnology analyst for the US investment bank Robertson Stephens, says the directors should not have sold shares "if they knew of questions to the viability of the batimastat study".

Equally controversial are allegations that
British Biotech withheld potentially damaging news from the stock market on problems with its anti-pancreatitis drug, zacutex.

In May 1997, the company learned that the European Medicines Evaluation Agency (EMEA) would not be recommending regulatory approval for zacutex on the basis of the company's initial application because of weaknesses in the clinical data. This coincided with UK trial results showing that the drug worked best if given within 48 hours of abdominal pain to patients with severe pancreatitis.

The circular says that the company was confident that the drug would still be approved if its application was amended to recommend early treatment to acute sufferers. A press release was issued indicating the zacutex trial results, and that an application had been made for regulatory approval.

The circular says that the board decided not to make public the EMEA decision, as it was preliminary, confidential and a development that was normal in the drug approval process.

But Woolf says the market should have been told of the preliminary decision. He says he appreciates the "fine line" that companies have to tread between transparency and losing investor confidence. But he says that British Biotech kept silent on the regulatory progress of zacutex for too long.

Millar, however, believes that more caution will strengthen the UK biotechnology industry, which he thinks is overvalued. "In the United States, they are much more mature, and have a regulatory system that dampens the hype," he says. EhsanMasood

\section{Germans mix support and scepticism for genetic engineering}

[MUNICH] Germany's biotechnology is booming in economic terms, but genetic engineering is still struggling to win public acceptance, according to two new reports.

One report, from the international consultants Ernst and Young, lists 173 small biotechnology companies in Germany, compared with 1,300 in the United States and 200 in the United Kingdom. In addition, 269 medium-sized companies have major activities in biotechnology.

The report says that as a result of strong political support in recent years including a closely managed university-industry competition, Bioregio, organized by the federal government (see Nature 379, 759; 1996) - investment is now strong in Germany.

The confidence of German investors is high, despite the fact that many companies are continuing to register heavy operating losses owing to high research costs and, as yet, few marketable products. In contrast, however, most Germans remain deeply suspicious of 'gene technology' — as genetic engineering is known in Germany — and the scientists who use it.

The second report, from a survey coordinated by the independent Stuttgartbased Centre of Technology Assessment (CTA) and financed by the federal research ministry, shows that three-quarters of those interviewed in 1997 believe that Germany's laws on gene technology are inadequate.

The survey, whose results were presented last week at a meeting in Bonn on public acceptance of gene technology, reveals that most of those questioned believe that the safety of genetic engineering cannot be guaranteed by laws.

Only three per cent of interviewees said they trusted genetic experts. Most believe such experts are required to reflect the opinions of their employers. Even those broadly in favour of gene technology have little confidence in the honesty and independence of genetics experts, according to the survey.

The CTA study also concluded that Germans differentiate "substantially" between gene technology and other advanced technologies, such as computing, telecommunications or space research. The latter are widely trusted to bring positive effects to society in the future. In contrast, expectations of gene technology are predominantly negative.

The report confirms the widely held notion that fears of the possible abuse of genetics, rooted in experience of the Nazi era, lie at the root of these negative attitudes. "Fears are fuelled by such ideas as eugenics, social selection, changes in the attitude towards handicapped people even the total reinterpretation of existence," say its authors.

Quirin Schiermeier 